\title{
The Impact of Foreign Labour on the Unskilled Labour Demand in Malaysia
}

\author{
Hussin Abdullah \\ School of Economics, Finance \& Banking, College of Business, Universiti Utara Malaysia \\ Email: hussin2141@uum.edu.my \\ Muhammad Azam \\ School of Economics, Finance \& Banking, College of Business, Universiti Utara Malaysia \\ Email:drazam75@yahoo.com \\ Muhammad Zakir Abdullah
}

School of Economics, Finance \& Banking, College of Business, Universiti Utara Malaysia

Doi:10.5901/mjss.2016.v7n1p264

\section{Abstract}

The main objective of this study is more on the unskilled labour input where the unskilled labour market is going to build across the Malaysian major sectors. It is evident that Malaysia has a large foreign labour market because of excess demand for labour, easily filled by foreign workers. For empirical investigation, this study uses a panel data analysis that consists of 12 years data of agriculture, manufacturing, and services sectors. The result of the Pedroni cointegration test shows that there are four out of seven panel statistics suggest the unskilled labor demand model is integrated within sectors. By using Fully Modified OLS (FMOLS), the finding demonstrates that only agriculture has long run- positive relationship with unskilled labor employment since this sector creates highest unskilled labor demand to fulfil the current production capacity and force this sector to hire also foreign labour.

Keywords: unskilled labour, foreign workers, cointegration, Pedroni, FMOLS, Malaysia

\section{Introduction}

In order to stay compete in the market and globalization pressure; firms tend to combine the best input to produce goods and services in an efficient and effective manner. There are three major input combinations that will boost production in Malaysia, which are labour inputs, capital inputs, and total factor productivity. The attention of this study more on the unskilled labour input where the unskilled labour market is going to build across the Malaysian major sectors. The previous study was focusing on the labour input aggregately (not distinguished between skilled and unskilled labour) in Malaysia case. The unskilled labour is defined in many ways where some study tends to define unskilled labour according to age, occupation and non-production or production labour, earning and ability to produce. However, in this study, unskilled labour is defined based on occupation in sectors.

In the Malaysian labour market, some of unskilled labour in industry was protected under the common agreements which claimed the setting of sustainable wage for unskilled labour. Every certain year, the setting of wage is going to be revised by a labour union. This indicated that labour union indirectly determines wage rate for some unskilled labour.

Actually, the trend of unskilled labour employment follows the trend aggregate labour employment that made. In 1978, the movement of labour employed gradually increase due to slower economic growth in 1977. More unskilled labour was employed in Agriculture sector like estate and forestry due to rapidly increasing of lumber and rubber price (Economics Report 1977/1978). However, the trend shifted to manufacturing sector in 1984 where industrialization activities are greatly increased. The industrialization in Malaysia led to create more labour demand growth at 4.3 percent. However, the construction sector was recorded as the highest labour demand growth (6.9 percent) where this sector suffered from the lack of unskilled labour employment. Interestingly, in Agriculture sector, the growth of unskilled employment drastically became slower at 1 percent due to migration of unskilled labour to the city and industrial areas (Economics Report 1984/1985).

In the late 1980s, the labour employment gradually grew due to slower economic activities in 1988. However, after 
the economic recovery in 1989, the manufacturing created a huge growth demand for unskilled labour at 16.4 percent. The higher demand for rubber and steel based product required more unskilled labour input in production. The agriculture still recorded the lowest labour employed at 1.3 percent, which many labour tends to migrate to cities. Services sector like retail, hotel and restaurant also likely to hire more unskilled labour and foreign labour (Economics Report 1988/1989).

In 1998, there were many labourers lost their job due to economic downsizing. Many firms cut their operation by employing less labour. Unskilled labour was the most affected by this recession and many foreign labourers were sent back to their own countries. The construction and agriculture were recorded negative 13 percent and 6 percent, respectively (Economics Report 1998/1999). After economic downsizing, the manufacturing created the highest vacancies where 2.45 million new jobs were offered in 2001. The government attempted to promote more skilled labour to participate in labour market rather than unskilled labour. Thus, the establishment of skill training institutes (for example MARA Vocational Institute and National Youth Training Institutes) tend to offer about 46.4 percent of skilled labour participant (Economics Report 2000/2001). It meant that the government seriously tried to reduce the number of unskilled workers in order to increase national productivity.

In moving toward developing country, government tends to execute policy that enhances productivity that can absorb the labour cost due to increase of nominal wage. In 2005, the Malaysian labour market tends participated by more skilled labour where there were 17.5 percent growths of graduate labour participation in the labour market. However, the participation of labour at Malaysian Certificate of Education (SPM) (about 50 percent growths) still greater than graduated labour (Economics Report 2004/2005).

The robust economic activities encouraged the employment for skilled and skilled labour to grow faster where more demand was created by the services sector at 51.5 percent growth. This indicated that the labour employment was shifted from manufacturing to services sector in 2007 (Economics Report 2007/2008). Towards 2012, services created more labour demand at 35.7 percent growth in services compared with 32.7 percent growth in manufacturing. The Labour participant consists of graduate student (60.6 percent), SPM level (27.7 percent). The growth of foreign labour was dropped by 4.5 percent. Skill Training Institutes will help to create more skilled labour to support the skilled labour demand (Economics Report 2011/2012).

Table 1: The percentage of skilled labour and unskilled labour to total employment

\begin{tabular}{ccc}
\hline Year & Percentage of skilled labour (\%) & Percentage of unskilled labour (\%) \\
\hline 2011 & 56.23 & 43.77 \\
2006 & 51.27 & 48.73 \\
2001 & 47.66 & 52.34 \\
1996 & 46.68 & 53.32 \\
1991 & 42.97 & 57.03 \\
1985 & 42.03 & 57.97 \\
\hline
\end{tabular}

Note: The DOS has opportunities available on a limited basis for researchers to access confidential data for purposes of conducting valid statistical analyses

Source: Department of Statistics Malaysia (DOS), 2012

Table 1 shows that the employment of unskilled labour was surpassing the employment of skilled Labour from 1985 until 2001. However, the trend of employment was dominated by skilled labour rather than unskilled labour in 2006. This phenomenon showed the many skilled labourers were produced through Universities and training skilled institute that fulfilled sector labour demand. In addition, the highly competitive market forced firm to increase productivity by hiring more skilled labour. However, it was not implied that the unskilled labour was not important in goods and services production. This is because the unskilled labour offered low labour cost compared to skilled labour.

Behind the Malaysian economic development, the unskilled labour employment was appeared to be a major contributor of productivity growth in certain sector like the Agriculture, Forestry and Fishing and Construction sectors (Productivity Report 2012/2013). However, the migration of foreign labourers in huge number to Malaysia seems to give impact on the unskilled labour employment. There were about one million foreign labourers out of eight million Malaysian labour forces (Migration News, 1995) and made Malaysia as the highest foreign labour share of total employment in Southeast Asia. The foreign labour employment tends to depress the unskilled labour nominal wage growth and also leaves the local- unskilled labour unemployed.

In order to fulfil the unskilled labour current demand, the employment of foreign labour cannot be avoided. Thus, the competition between the local which is unskilled labour and the cheaper foreign labour will yield unemployment occur. 
In addition, recently the Minimum Wage Policy which announced by the Prime Minister of Malaysia, Dato' Seri Najib bin Tun Abdul Razak in 2012 is expected to give a vulnerable impact on employment of unskilled labour. The Minimum wages are allowed to be standardized at national level where the wage settings are above than the poverty line (RM 900 at Peninsular of Malaysia and RM 800 at Sabah and Sarawak). The unskilled labour employment is expected to deflate since the nominal wage relative of skilled labour to unskilled labour is expected decrease by the meaning of the Minimum Wage Policy. Thus, unskilled labour will be switched with the higher skilled labour or labour-saving technology input. The local-unskilled labour employment is appeared to compete with the higher skilled labour and foreign labour employment.

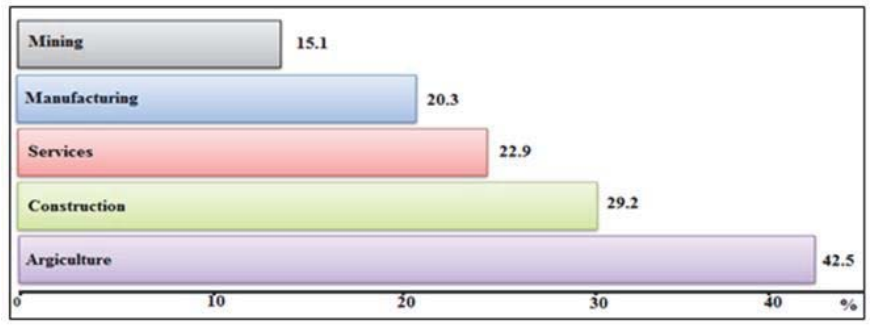

Figure 1: The share of Unskilled Labour (Peninsular of Malaysia) that earned below than RM800 across Malaysian sectors 2012.

Source: Bank Negara Malaysia, 2012.

Figure 1 shows that The Agriculture and Construction were amongst the highest unskilled labour employment share were 42.5 and 29.2 percent respectively. Meanwhile, the Services, Manufacturing and Mining only employed 22.9, 20.3 and 15.1 percent respectively. The Agriculture and Construction where the highest foreign labor employment where about 30 percent of unskilled labor employment consisted of foreign labor employment (Migration News, 1995) in 1994.

The existing literature reveals that the issue of unskilled labour employment is concerned in this study since foreign labour can influence unskilled labour employment. The presence labour, foreign labors can be a good reason for why government seriously tries to improve unskilled labour to higher skill. The broad objective of this study is more on the unskilled labour input where the unskilled labour market is going to build across the Malaysian major sectors. It is evident that Malaysia has a large foreign labour market because of excess demand for labour, easily filled by foreign workers. Foreign workers inflows have long been used to meet the domestic labour market demand because it well contributes into the economic growth and development. It has been observed that relatively skilled labour is a key input to an innovative economy. The researchers did not find any relevant study on the topic under the study; therefore, this is the first inclusive study pertinent to the labour market, unskilled labour input and the significance of foreign labour in the context of Malaysia. The outcomes will certainly guide the policy makers regarding policy relevant to foreign workers inflows. It will also contribute to literature on the significance of skilled foreign workers inflows and their role in promoting economic growth.

This paper is structured into sections, they contain: Section I above, which concisely shed lights on the introduction of the study. Section II deals with the review of relevant literature. Section III presents empirical methodology, data model specification and estimation procedure. Section IV presents results and discussion. Finally, Section V concludes the paper.

\section{Literature Review}

This section is organized according to issues of the impact of foreign labour on unskilled labour demand that have been discussed in previous studies. Labour, employment generally is related to the phases of the business cycle. Labour is likely to be employed during the expansionary of business cycle phase and less employed during economic downsizing. At latest business cycle expansionary, unemployment is decreasing, drives up wage rate and lowering labour, capital intensity and labour productivity (Mouhammed, 2012). Thus, after the peak of business cycle expansionary, the employment is starting to reduce.

The employment of foreign is the most affected during economic recession. Such Germany and United Kingdom's case (Dustmann et al., 2010), the foreign labour employment tends to reduce greatly compared to native employment during economic recession, but at the phase of recovery, the foreign employment is starting to grow. By decomposing 
change in outcomes into secular trend and business cycle component, Dustman et al., (2010) found that there was unemployment differential between foreign labour and native labours over the business cycle. At the same level of education and age, foreign labourers from non-OECD countries is the most suffered from unemployment at economic downsizing phase. However, there is no wage differential between foreign labour and native economic downsizing phase. This result concluded that foreign labour employment is more sensitive to business cycle phase. The less complementary of foreign labor with capital employed and the foreign labor likely to perform production jobs rather than management jobs explains why foreign labor loses job faster than native labor during the economic downturn but gain job faster during economic recovery.

There are some discrimination and underprivileged position of labour, foreign labour compared to native labour. Foreign labour seems less likely to be employed even the cost of employing foreign labour is cheaper than native labour at the same level of education and age. Ward and Masgoret (2007) conducted a study where two types of resumes; a Chinese-born resume and native-born resume were sent to companies in the Australian technology sector. In addition, the china-born and native-born candidates have the same level of education and working experience. The result showed the china-born candidate disengage (being told there is no job opportunity) more frequently compared to native-born. The foreign labour seems a disadvantage to engage in the labour market that caused by ethnicity, English proficiency and unreceptiveness of employers to overseas qualification \& experience. The foreign labour also seems to be discriminate by means of labour union. A labor union appears to less care about foreign labor employment (Kwon \& Chun, 2011).

The foreign immigrant that did not influence the wage rate of native labour (for all skill level labour) explains the imperfect substitution of foreign labour with native labour. New immigrants are likely to compete with other immigrant rather than native labour. Thus, the wage competition among foreign labour does not reduce native employment since the wage rate of native labour does not affect (Peoria, 2011).

By adapting the structure of national (United State approach to local area (California) and using Two Stage Least Square, Peoria (2011) examine how substitutes the foreign labour with native labour in California. Native labour tends to do more specialization in production as a response to the immigrant labour from another state in the US and Mexico. As a result, the increasing productivity for each skill- native labour group absorbs the negative employment effect. The study of Perry (2011) also suggested there is another unobserved pull factor that attracted foreign labour to US that lifts up the wage relative of foreign labour to native since there was a correlation between the variable of foreign labour with residual in the finding.

In a study, Kemnitz (2008) investigated that how immigrant employment influences public pensions (demographic burden of social security) under union centralization. Foreign labour only can alleviate the demographic burden only if native employment is decreasing. Pension payment is a constant fraction of the total wage and the pension payment tends to increase when total wage is increasing. The consequence of foreign employment will reduce native employment and increase the total wage (if labour demand is inelastic) and increase total pension eventually. Thus, Kemnitz (2008) concluded hiring more foreign labour will lead to increase social security (alleviates demographic burden) even the native employment is dropping. Similarly, Kwon and Chun and (2011) using bivariate Tobit models to examine the relationship between foreign labour with temporary labour employment. The new-establish firms are more likely to hire foreign labour and temporary labour compared to established firms. This means that the-new establish firms tend to employ labour, save-cost of production. The firms try to reduce costs at the beginning of establishment by hiring temporary labour rather than permanent. The wage payment was found to be negatively affected by foreign labour and temporary labour employment. Moreover, the study also explains less skilled labour, employment substitute likely to be replaced by temporary worker rather than foreign labour. Since there is a less female labour work in production task, the foreign labour also employed along with female labour. This will be the reason why the foreign labour complements with temporary and female labours.

Since most of unskilled labour and foreign labour share the same level of education and skill, the trade openness tends to attract more foreign employment (Rutiyya \& Photo, 2008) and replace the unskilled labour employment. Bergin \& Kearney (2007) were derived unskilled labour demand from Constant Elasticity Substitution (CES) function of Ireland's case. The result suggests there is a negative effect of unskilled labour, employment by mean of foreign labour participation in the labour market but the magnitude is small. Besides that, Sayre (2011) suggests that wage gaps between skilled and unskilled labour was getting smaller since there were many Palestinian unskilled labours migrate out from Palestine to abroad.

In services, the lack of unskilled labour supply motivates firms to hire more foreign labour in order to boost productivity growth. Foreign labour came to replace native labour employed in the service sector (Kwon \& Chun, 2011) as the real wage of native labour is increasing. Wye \& Rahmah (2012) found that the major source of labour productivity in Malaysia is coming from quantity of labour instead of Total Labour Productivity, TFP and suggested that Malaysian 
service mostly relies on foreign labour.

Some production good and service that employed imported input likely to influence unskilled labour employment. Agenor (2005) treated employment of unskilled and skilled labour as dependent variable and wages of skilled and unskilled labour, minimum wage rate government services price and real exchange rate as independent variables. In this study real exchange rate is considered as the price of imported inputs. The depreciation of real exchange rate will lead to increase wages at equilibrium and unskilled labour employment. However, Vu (2012) suggested, imported capital was more likely to replace skilled labour rather than unskilled labour for Australia case. The study of Mouhammed (2012) employed a simple function to determine the unemployment problem with the productivity of labour where more productivity, lowered unemployment through increasing of total revenue relative to wages. As suggested by Wye \& Rahmah (2012) that labour quantity is the major contributor to productivity, labour growth in Malaysia, thus, hiring more labour tend to create productivity labour growth.

The wage rate is the important variable that can determine unskilled labour employment. Baffoe-Bonnie and Gyapong (2012) employed the Structural Vector Autoregression (SVAR) to explain dynamic effect wages changes in Ghana suggested that the short run effect of increasing of wages in the manufacturing sector was resulting more labour hire. The study of Selamah (2008) examined the dynamic behaviour of real wages, employment and productivity, which associated with Classical and neoclassical, Keynesian, Performance based Pay Scheme, PBP and Wage Theory on Malaysian Manufacturing Sector. This study suggested higher wages help to improve more labour productivity by allowing labour to receive higher nutrition and medical care that preserved their health and physical ability and lead to higher employment. In contrast, Ho and Yap (2001) employed Error Correction Model (ECM) to analyse long run and short run dynamic change of wages across 13 selected Malaysian manufacturing subs-sector found that there is negative relationship between wage and labour employed in the sectors.

The study of Selamah (2008) suggested the higher wage turned labour, employment to be substituted with capital due to higher labour costs in Malaysian case. Thus, unskilled labour, employment is suffering from job losses if the wage is increasing, but labour productivity remains unchanged or slow. In a similar study, Vu (2012) examined the impact of import on demand for skilled and unskilled labour of Australia by employing unit cost function and found that there is positive relationship between capital price and labour employment. This means that capital tends to be substituted with labour employment.

\section{Empirical Methodology}

The type of data that employed in this study is panel data to overcome the lack of 30 years in time series data. This secondary data consists of 12 years data of manufacturing, agriculture and services sectors. The other data limitation is the difficulty to obtain the data for wage and unskilled employment in these three sectors directly. The data can be only obtained via doing some calculation.

For agriculture data, the only possible measure of unskilled labour, employment and unskilled nominal wage data (secondary data) is by using the number of workers at rubber estate and the wage paid to the workers as representation. For Manufacturing and Services the data can be indirectly obtained by doing some calculation. All these data can be available at The Monthly Rubber Report and Yearbook the Statistic of Malaysia.

The authors' data like capital price, imported input price and foreign labour are not difficult to find. The capital price is the measure of interest of lending rate, and the imported input price is a measure of the exchange rate (Cerda \& Larrain, 2010). Meanwhile, foreign labour employment is measured by the percent of foreign labour on total employment. These data can be obtained at the Statistic Department of Malaysia website and International Monetary Fund Yearbook.

\subsection{Model}

Con (2012) proposed the labour demand is built as follows:

$\mathrm{L}=\mathrm{L}(\mathrm{W}, \mathrm{Q}, \mathrm{X})$

Where $\mathrm{Q}$ is output or GDP, $\mathrm{W}$ is wage rate and the $\mathrm{X}$ is another demand factor variable. In a study, Baffoe-Bonnie and Gyapong (2012) derived labour demand by using Structural Vector Autoregeression, SVAR to look at dynamics implication as follows:

$$
\mathrm{L}=\mathrm{f}(\mathrm{T}, \mathrm{W}, \mathrm{e}, \mathrm{Q}) \text {. }
$$

Where the T is Technology and e is productivity. This study will not employ variable output and labour productivity (Output divided by labour) together to avoid from the serious Multicollinearity problem. Variable technology (Total Factor Productivity) is also dropped as technology not gives strong effect on output per labour (Wye \& Rahmah, 2012) for 
Malaysian case. Thus, by adding variable foreign labour, employment, capital price and imported input price, thus, the unskilled labour demand model is built as follows:

$\mathrm{L}_{\mathrm{it}}=\beta_{0}+\beta_{1} \mathrm{~W}_{\mathrm{it}}+\beta_{2} \mathrm{Q}_{\mathrm{it}}+\beta_{3} \mathrm{I}_{\mathrm{t}}+\beta_{4} \mathrm{Exc}_{\mathrm{t}}+\beta_{5} \mathrm{Fl}_{\mathrm{t}}+\varepsilon_{\mathrm{t}}$

where,

$\mathrm{L}_{\mathrm{t}}=$ Unskilled Labour Employed at time tin sector $i$

$\mathrm{W}_{\mathrm{t}}=$ nominal wages paid to unskilled labour at time $\mathrm{t}$ in sector $i$

$\mathrm{Q}_{\mathrm{t}}=$ Output produces at time $\mathrm{t}$ in sector $i$

$\mathrm{I}_{\mathrm{t}}=$ Price of capital at time $\mathrm{t}$

Exc $_{\mathrm{t}}=$ Price of imported input at time $\mathrm{t}$

$\varepsilon_{\mathrm{t}}=$ error termat time $\mathrm{t}$

Note that they are no need to employ real wage and real output in this model where:

$\mathrm{R}_{\mathrm{t}}=\frac{\mathrm{W}_{\mathrm{t}}}{\mathrm{P}_{\mathrm{t}}}$ and $\mathrm{Y}_{\mathrm{t}}=\frac{\mathrm{Q}_{\mathrm{t}}}{\mathrm{P}_{\mathrm{t}}}$

where,

$\mathrm{R}_{\mathrm{t}}=$ Real wage at time t.

$\mathrm{Y}_{\mathrm{t}}=$ Real output at time $\mathrm{t}$.

$\mathrm{W}_{\mathrm{t}}=$ Nominal wage at time $\mathrm{t}$

$\mathrm{Q}_{\mathrm{t}}=$ Nonimal output at time $\mathrm{t}$

$\mathrm{P}_{\mathrm{t}}=$ Deflator factor at time $\mathrm{t}$.

of The Equation 3.4 is transformed into logarithm form

$\log \left(\frac{W_{t}}{P_{t}}\right)=\log W_{t}-\log P_{t}$ and $\log \left(\frac{Q_{t}}{P_{t}}\right)=\log Q_{t}-\log P_{t}$

The variable $\log \mathrm{P}_{\mathrm{t}}$ will be absorbed by the intercept in the model (Wooldrige, 2013). The coefficients of $\beta_{1}, \beta_{2} \beta_{3}$, and $\beta_{4}$ Should be ambiguous since there are various theories that suggest negative and positive sign for the $\beta_{1}, \beta_{2} \beta_{3}$, $\beta_{4}$ and $\beta_{5}$.

\subsection{Estimation Procedures}

The Estimation of this study concern about the dynamic effect of foreign labour on skilled labour demand. Thus, the Pedroni Cointegration test with multiple regressors and the Fully Modified OLS are suited in this analysis for heterogeneous panel data of unskilled labour demand are employed (Hassan, et al., 2014 and Abdullah, et al., 2007). The Unit Root test for panel should be executed first so that the stationary of data can be determined.

\section{Result and Discussion}

\subsection{Unit Root Test}

The Augmented Dickey Fuller (ADF), the ADF unit root test is presented in the following Table 2:

Table 2: Unit Root test result of the variables in unskilled labour demand model

\begin{tabular}{|c|c|c|c|c|}
\hline \multirow[b]{2}{*}{ Variable } & \multicolumn{2}{|c|}{ Level } & \multicolumn{2}{|c|}{ First Difference } \\
\hline & Intercept & Intercept \& Trend & Intercept & Intercept \& Trend \\
\hline \multirow{2}{*}{$\log L$} & 7.94576 [2] & 17.189 [1] & $-396520^{\star \star \star}[0]$ & $-5.94502 * * *[0]$ \\
\hline & 0.9999 & 0.9999 & 0.0001 & 0.0001 \\
\hline \multirow{2}{*}{$\log W$} & $5.19448[1]$ & $17.9236[1]$ & $-44.2906^{\star \star \star}[0]$ & $-5.43723 * * \star[0]$ \\
\hline & 0.9999 & $0.9999^{\circ}$ & 0.0001 & 0.0001 \\
\hline \multirow{2}{*}{$\log Q$} & $-0.92935[1]$ & $-1.27494[0]$ & $-4.85062^{\star \star \star}[0]$ & $-5.26313^{\star \star \star}[0]$ \\
\hline & $0.1764^{\circ}$ & $0.1012^{2}$ & 0.0001 & 0.0001 \\
\hline \multirow{2}{*}{$\log \mathrm{FI}$} & $1.15843[0]$ & $-2.27065[0]$ & $-5.87057^{\star \star \star}[0]$ & -3.38428 *** [1] \\
\hline & 0.8767 & 0.0116 & 0.0001 & 0.0004 \\
\hline \multirow{2}{*}{$\log \mid$} & $-0.9668[0]$ & $-1.11788[1]$ & $-1.49192^{\star \star}[0]$ & $-0.48497[0]$ \\
\hline & 0.1668 & 0.1318 & 0.0679 & $0.3138^{\circ}$ \\
\hline \multirow{2}{*}{$\log E x c$} & $1.15843[0]$ & 9.97075 [2] & $-5.87057^{* \star *}[0]$ & $-3.38428[1]$ \\
\hline & 0.8767 & 0.0009 & 0.0001 & 0.0004 \\
\hline
\end{tabular}

Note: $\left.{ }^{* * *}\right)$ indicates the rejection of hypothesis null of non-stationary at 1 percent level of significance. 
$\left({ }^{*}\right)$ indicates the rejection of hypothesis null of non-stationary at 5 percent level of significance.

[] indicates the lag specified

( ) indicates t-statistical probability value

The unit root test in conducting on variables in the model where the all variables are assumed to share common unit root process according to Levin, Lin \& Chu test. The lag length selected for this test is based on Akaike Info Criterion automatic selection and self-user-lag adjusted. Table 2 suggests that all variables have unit roots at the level, but stationary have no unit root at the first difference (except for an interest rate at the first difference with intercept and time trend). The requirement of non-stationary at a level and stationary at first difference in order to conduct cointegration test is fulfilled.

\subsection{Cointegration Result}

The Residual Pedroni Cointegration test allows the model to determine the long run relationship or not from panel data. The relationship can be tested by via Panel V- Stat, Panel Rho- Stat, Panel PP- Stat, Panel Adf- Stat, Group Rho- Stat, Group PP- Stat and Group Panel PP. Stat. If these statistic values are found statically significant then, the model is verified to have a long run relationship. For the panel statistic, if there is a common AR coefficient within dimension, the model should be cointegrated. The Null Hypothesis stated that there is no common AR coefficient within dimension which also means there is no cointegration in the unskilled labour demand model.

Table 3: Pedroni Residual Cointegration Test for panel statistic

\begin{tabular}{lc}
\hline & Statistic \\
\hline Panel V- Stat & $3.33559^{\star \star \star}$ \\
Panel Rho- Stat & 0.92739 \\
Panel PP- Stat & $-6.12392^{\star \star \star}$ \\
Panel Adf- Stat & $-5.5476^{\star \star \star}$ \\
Group Rho- Stat & $2.52372^{\star \star \star}$ \\
Group PP- Stat & -0.81875 \\
Group Adf- Stat & -0.40821 \\
\hline
\end{tabular}

Note: $\left.{ }^{* * *}\right)$ indicates the rejection of hypothesis null of non-stationary at 1 percent level of significance.

The result given in Table 3 indicates that only the Panel Rho- Stat insignificant at any significant level. The Panel V-Stat, PP- Stat and Adf- Stat are significant as one percent where there is a common AR coefficient within sectors (Agriculture, Manufacturing and Services). In other words, three out of four panel statistics suggest the unskilled labour demand model is cointegrated within sectors.

For Group statistic, the hypothesis alternate state, there is significant individual AR coefficient between sectors which means an unskilled labour demand model is cointegrated between sectors. The result indicates that only the Group Rho- Stat significant at one percent significant level where there is a significant individual AR coefficient between sectors (Agriculture, Manufacturing and Services). The PP- Stat and Adf- Stat is insignificant at any significant level. In other words, one out of four group statistics suggests the unskilled labour demand model is cointegrated within sectors.

\subsection{Fully Modified OLS}

The Fully modified OLS is a method for estimating cointegration vector in dynamic panel data which allow considerable heterogeneity across individual members of the panel. The advantage of using this method is the group mean estimator is behaving well, even in a relatively small sample under a variety of scenarios (Pedroni, 2000). Interestingly, this approach gives the long run relationship between dependent variable and independent variable across the sector. By using RATS, the results of Fully Modified OLS are reported in Table 4. 
Table 4: Individual Fully Modified OLS result

\begin{tabular}{lccccc}
\hline Variable & LogW & LogQ & LogEXC & Logl & LogFL \\
\hline Agriculture & $0.23^{\star \star \star}$ & $-0.27^{\star \star \star}$ & $-0.08^{\star \star \star}$ & $1.29^{\star \star *}$ & $0.74^{\star \star *}$ \\
& $(3.97)$ & $(-3.77)$ & $(-2.80)$ & $(4.85)$ & $(5.08)$ \\
Manufacturing & $0.80^{\star \star \star}$ & $-0.19^{\star \star \star}$ & -0.01 & 0.06 & 0.08 \\
& $(13.67)$ & $(-3.54)$ & $(-1.21)$ & $(0.66)$ & $(1.08)$ \\
Services & $0.81^{\star \star \star}$ & $-0.11^{\star \star \star}$ & -0.001 & -0.01 & 0.01 \\
& $(59.95)$ & $(-6.48)$ & $(-0.08)$ & $(-0.39)$ & $(0.73)$ \\
\hline
\end{tabular}

Note: $\left({ }^{* \star}\right)$ indicates the rejection of hypothesis null of non-stationary at 1 percent level of significance. ( ) Indicates $\mathrm{t}$ statistic value

The Individual Fully modified OLS in Table 4 proposed that there is positive influence of the growth, nominal wage paid to unskilled labour on the growth of unskilled labour employment and significant at one percent. This result consistent with the Performance Based Pay Scheme Theory PBP, where increasing of wage gives a chance for unskilled labour to improve their health condition and motivates more effort in production and create more jobs (Selamah, 2008; Kon, 2012) in the long run. However, the productivity has significantly negative impact on unskilled labour employment at one percent. This result suggests the unskilled labour will earn more experience and efficiency in production due to specialization in long term. The current experienced unskilled labour tends to produce more without hiring more new unskilled labour (Selamah, 2008). As a result, the growth of productivity creates a negative effect on the growth of unskilled labour demand.

The growth of imported input price and capital price significantly affected the growth of unskilled labour employment in agriculture at one percent, but insignificant in manufacturing and services at any significant level. In agriculture, the increasing of imported input price tends to cut unskilled labour employment suggests the imported inputs and unskilled labour input complements each other (the positive relationship between unskilled labour and imported inputs). The imported input is likely to decrease skilled labour demand ( $V u, 2012)$ but produced a higher demand for unskilled worker. The capital price growth has positive effect on unskilled labour growth where implied that the relationship between unskilled labour and capital was substitution input (Rich, 2012) in agriculture. The rental rate (capital price) increased tend to shift from unskilled labour employment to capital employed (Vu, 2010).

The growth of foreign labour employment is positively associated with the growth of unskilled labour in agriculture at one percent sign, but insignificant for manufacturing and service at any significant level. This result means that unskilled labour employment is accompanied by foreign labour employment in agriculture production (complementary input). Since the agriculture creates the highest demand for unskilled labour (Bank Negara Malaysia, 2012), the foreign labourers no longer reduce unskilled labour demand but these inputs are employed together. Finding also said there is no job destruction on unskilled labour in manufacturing and services that created by foreign labour. Kwon and Chun (2011) suggests less skilled labour employment substitute likely to be replaced by temporary worker rather than foreign labour.

Table 5: Panel Group Fully Modified OLS result

\begin{tabular}{cccccc}
\hline Variable & LogW & LogQ & LogEXC & Logl & LogFL \\
\hline \multirow{2}{*}{ Coefficient } & $0.81^{* * *}$ & $-0.11^{* * *}$ & -0.001 & -0.01 & 0.01 \\
& $(59.95)$ & $(-6.48)$ & $(-0.08)$ & $(-0.39)$ & $(0.73)$ \\
\hline
\end{tabular}

Note: $\left.{ }^{\star \star *}\right)$ indicates the rejection of hypothesis null of non-stationary at 1 percent level of significance. ( ) Indicates $t$ statistic value

It is evident from Table 5 that Panel Group Fully Modified OLS result also consistent with the Individual Fully Modified OLS result (except for $\log E X C$, log me and logFL in agriculture). The growth of nominal wage paid to unskilled labour is positively associated with the growth of unskilled labour employment at one percent significant. The growth of productivity is negatively affected by the growth unskilled labour employment at one percent significant. However, the growth of imported input price, capital price and foreign labour employment is insignificantly affected unskilled labour employment growth at any significant level.

\section{Conclusion and Policy Implications}

The aim of this study is to empirically investigate that weather is there any job destruction for unskilled labour by hiring 
foreign labour in the context of Malaysia. For this purpose, we use a panel data approach that consists of 12 years data of agriculture, manufacturing, and services sectors. By using fully modified OLS, the long run impact of foreign labour employment on unskilled labour demand is obtained. The finding concludes only agriculture have long run- positive relationship with unskilled labour employment since this sector creates highest unskilled labour demand to fulfil the current production capacity and force this sector to hire also foreign labour. The unskilled labour and foreign labour in agriculture is complementary input. There is no long run effect on manufacturing and services by means of foreign labour employment. The overall result suggests that there is no job destruction for unskilled labour by hiring foreign labour in the country.

The findings of this study suggest that policy makers need to devise policy pertinent to skilled foreign workers inflow in order to alleviating pre-existing skill labour shortages in Malaysia. Consequently, relatively more skilled foreign workers inflows will increase largely output in all sectors and raise the rate of economic growth in the country. However, the expertise of foreign workers should be utilized more effectively to increase productivity maximally. Furthermore, selective policies related to foreign workers must be devised only within limits, and it will need more in-depth consideration to develop suitable policies. While, it is also imperative to prepare and trained Malaysian's present and future generations to mitigate labour shortage in the country.

\section{References}

Abdullah, H., Habibullah, M.S., Baharunshah, A.Z., \& Hui, T.B. (2007). Long Run Relationship between Fiscal Policy and Economic Growth in Asian Economies: Evidence using Pedroni's Cointegration Approach. Malaysia Management Journal (MMJ) II (1\&2), 49-67

Agènor, P. R. (2005). Fiscal Adjustment and Labour Market dynamics in an Open Economy. Journal of Development Economic, 76, 97125.

Bergin, A., and Kearney, I. (2007). Human Capital Accumulation in an open Labour Market. Economic Modelling, 24, $839-858$.

Bank Negara Malaysia. (2012). Potential Impact of Minimum Wages on the Malaysian Economy. Retrieved from www.bnm.gov.my/files/ publication/ar /en/2012/cp04_005_box.pdf

Baffoe-Bonnie, J and Gyapong, A. O. (2012). The Dynamic Implications For Wages Changes in Productivity, Prices and Employment in Developing Economy: A Structural VAR analysis. Journal of Developing Areas. 46(2), 397-417

Cerda, R. A. and Larrain, F. (2010). Corporate taxes and the demand for labor and capital in developing countries. Small Business Economics, 34( 2), 187-201

Dustmann, C., Glitz, A,. \& Vogel, T., (2010). Employment, wages, and the economic cycle; Differences between immigrant and natives. European EconomicReview, 54, 1-17

Department of Statistics Malaysia. Retrieved from https://www.statistics.gov.my/

Ho, L. P and Yap, S. F. (2001). The link between Wages and Labour Productivity: An analysis of Malaysian Manufacturing Industry. Malaysian Journal of Economics Studies, 38 (1), 51.

Hassan, S., Abu Bakar, N.A., \& Abdullah, H. (2014). Analysis of FDI Inflows into China from ASEAN-5 Countries: A Panel Cointegration Approach. Journal of Economic Cooperation and Development, 35 (3), 1-28.

Kemnitz, A. (2008). Can immigrant employment alleviate the demographic burden? The role of Union centralization. Economics Letters, $99(1), 123-126$

Kon, C, C. (2012). Economic Growth and Employment in the Equilibrium Labour Market. The Business Review, Cambridge, 20 (2).

Kwon, Chul-Woo and Chun, B. G, (2011). Relationship regarding the demand for labour between domestic temporary and foreign workers: Korean case. Japan and the World Economy, 23 (4), 240-245

Migration News. (1995). Retrieved from http://migration. ucdavis.edu/ mn/more.php?id=571_0_3_0.

Mouhammed, A.H. (2012). Unemployment and Productivity in the American Economy. Journal of Applied Business and Economics, 13 (4), $52-58$

Pedroni, P. (2000). Fully Modified OLS for Heterogeneous Cointegrated Panels. Nonstationary Panels, Panel Co intergration and Dynamic Panels. 15.

Peri, G. (2011). Rethinking the area approach: Immigrants and the labour market in California. Journal of International Economics. 84

Rich, D.P. (2010). Changing Elasticities of Labour Demand in U.S Manufacturing. Atlantic Economic Journal, 38(2), 157-168

Rutiyya, B. and Paitoo, K. (2008). Trends of labour demand for high -skilled workers and their wages in Thailand. Journal of International Business Research. 7(1). Retrived from http://www.freepatentsonline.com/article/Journal-International-BusinessResearch/204419291.html

Selamah, A. Y., (2008). The long-run and dynamic behaviors of wages, productivity and employment in Malaysia. Journal of Economic Studies, 35 (3), $249-262$

Sayre, E. A. (2001). Labour Demand and the wage gap in the west bank and Gaza Strip. Contemporary Economic Policy, 19(2),213224.

Ward, C. and Masgoret, A. M. (2007). Immigrant Entry into the workforce: A research note from New Zealand. International Journal of Intercultural Relation, 31(4), 525-530 
Wooldrige, J. M. (2013). Introductory Econometrics A Modern Approach. $5^{\text {th }}$ edition. Souhth- Western Cangage Learning: Canada.

Wye, C.K and Rahmah, I. (2012). Sources of Labour Productivity Growth by Economics Sectors; A study of Malaysia $1972-2005$. International Journal of Management. 29(2) 